\title{
PENGARUH KEMAMPUAN BERPIKIR STATISTIK TERHADAP KREATIVITAS BERPIKIR SISWA DALAM MATEMATIKA (Studi Kasus di Kelas XI IPA MAN 2 Kota Cirebon )
}

\author{
Reza Oktiana Akbar, Rachmawati Tsoraya \\ Jurusan Pendidikan Matematika, Fakultas Tarbiyah, IAIN Syekh Nurjati Cirebon, \\ Jalan Perjuangan By Pass Cirebon 45132, Indonesia \\ Telepon : +62 231481264
}

\begin{abstract}
ABSTRAK
Kreativitas merupakan suatu hal yang jarang sekali diperhatikan dalam proses pembelajaran matematika. Guru biasanya menempatkan logika lebih tinggi dan menganggap kreativitas hal yang tidak penting dalam pembelajaran matematika. Berdasarkan informasi yang disampaikan oleh Ibu Nunung (Seorang Guru bidang Matematika di MAN 2 Kota Cirebon), menyatakan bahwa "mayoritas siswa mengerti ketika guru menerangkan materi dan contoh soal.

Ketika siswa diberikan soal yang sedikit berbeda, mereka pun agak kesulitan menjawabnya". Hal ini dikarenakan kemampuan kreativitas berpikir siswa dalam memanipulasi matematika masih sangat kurang, akibatnya siswa kurang berkesempatan untuk mengembangkan kreativitas yang dimilikinya dalam menyelesaikan soal matematika secara maksimal.

Penelitian ini bertujuan untuk mengetahui, a) Bagaimana kemampuan berpikir statistik siswa dalam menyelesaikan soal matematika. b) Bagaimana kreativitas berpikir siswa untuk menyelesaikan soal matematika. c) Apakah terdapat pengaruh kemampuan berpikir statistik terhadap kreativitas berpikir siswa dalam matematika.

Kemampuan berpikir statistik merupakan salah satu fokus pembelajaran matematika yang diharapkan mampu menumbuhkembangkan kreativitas siswa dalam belajar matematika. Kreativitas berpikir berarti kemampuan yang mengarah pada penemuan ide-ide baru melalui pendekatan baru dan berpikir fleksibel dalam memecahkan masalah secara mudah dengan menekankan pada aspek kelancaran (fluency), keluwesan (flexibility), kebaruan (originality), dan keterincian (elaboration).

Pendekatan yang digunakan adalah pendekatan kuantitatif, sedangkan metode penelitiannya menggunakan metode expost facto. Populasi dalam penelitian ini adalah seluruh siswa kelas XI MAN 2 Kota Cirebon yang berjumlah 290 siswa, sedangkan pengambilan sampel menggunakan teknik purposive sampling dengan mengambil satu kelas dari tujuh kelas yaitu kelas XI IPA 2 yang berjumlah 34 siswa sebagai sampel penelitian. Adapun teknik pengumpulan data menggunakan tes uraian. Setelah data diperoleh, kemudian data dianalisis secara deskriptif dan dilakukan pengujian statistik berupa uji regresi.

Setelah dilakukan penelitian dan pengolahan data menggunakan software SPSS 16.0, diperoleh rata-rata tes kemampuan berpikir statistik siswa sebesar 65,29, yang tergolong kriteria cukup dan rata-rata tes kreativitas berpikir matematika siswa sebesar 70,96 tergolong kategori kreatif, yang artinya siswa mampu menunjukkan berbagai macam penyelesaian meskipun tidak dengan cara yang berbeda. Persamaan regresi yang dihasilkan yaitu dengan koefisien determinasi sebesar 37,8\%. Hal ini diartikan bahwa pengaruh kemampuan berpikir statistik terhadap kreativitas berpikir siswa sebesar $37,8 \%$, sedangkan sisanya $62,2 \%$ ditentukan oleh faktor lain diluar variabel yang digunakan dalam penelitian ini.
\end{abstract}

Kata Kunci : Kemampuan berpikir statistik, Kreativitas berpikir siswa dalam matematika.

\section{PENDAHULUAN}

Pada dasarnya untuk dapat melakukan kegiatan berpikir ilmiah yang baik perlu ditunjang dengan sarana berpikir ilmiah berupa bahasa, logika, matematika, dan statistika. Ditinjau dari pola berpikirnya maka ilmu merupakan gabungan antara berpikir deduktif dan induktif. Berpikir menggunakan logika induktif erat hubungannya dengan penarikan kesimpulan dari kasus-kasus individual nyata menjadi kesimpulan umum. Sedangkan, berpikir menggunakan logika deduktif membantu dalam menarik kesimpulan dari hal yang bersifat umum menjadi khusus yang bersifat individual (Suriasumantri, 2003: 213). 
Statistika relatif sangat muda dibandingkan dengan matematika, dewasa ini statistika berkembang dengan sangat cepat terutama dalam dasawarsa lima puluh tahun belakangan ini. Statistika merupakan pengetahuan yang memungkinkan kita untuk menarik kesimpulan secara induktif berdasarkan peluang. Statistika merupakan disiplin ilmu tersendiri yang berbeda pola berpikirnya dari matematika. Matematika mempunyai peran yang penting dalam berpikir deduktif, sedangkan statistika berperan penting dalam pola berpikir induktif. Matematika dikatakan deduktif karena beranjak dari aksioma dan teorema sehingga memunculkan penalaranpenalaran, modelmodel dan bukti baru berdasarkan aksioma dan teorema yang telah ada sebelumnya. Statistika, dengan situasi yang sama dan data yang sama pula bisa memberikan cara menganalisis yang berbeda dan memunculkan kesimpulan yang berbeda pula. Hal itu membutuhkan penalaran induktif, bekerja dengan randomisasi (pengacakan), pengambilan kesimpulan yang sesuai dan menginterpretasi hasil yang didapat.

Pada hakekatnya proses berpikir diperlukan setiap orang dalam melakukan aktivitas kehidupan sehari-hari. Proses berpikir diperlukan setiap orang untuk dapat bertahan pada keadaan yang selalu berubah, tidak pasti dan kompetitif saat ini. Hal ini diperlukan agar seseorang mempunyai kemamuan untuk memperoleh, memilih dan mengolah informasi. Kemampuan ini membutuhkan pemikiran kritis, sistematis, logis, dan kreatif serta mempunyai kemampuan bekerjasama yang efektif. Menurut Robert Epstein (Machrus, 2012: 2), seorang psikolog mengatakan bahwa setiap manusia memiliki kemampuan kreatif. Dengan demikian, tidak ada alasan kita mengatakan "saya bukan orang yang kreatif", yang ada hanyalah belum mengasah potensi kreativitas yang dimilikinya. Kreativitas bisa terjadi jika seseorang mencoba sesuatu dengan sengaja, dari sengaja maka seseorang tersebut mampu untuk mangembangkan potensi dan kemampuannya secara optimal, dan akhirnya menjadi terbiasa untuk berkreasi.

Salah satu fokus tujuan pembelajaran matematika adalah siswa memiliki kemampuan berpikir yang kreatif agar menciptakan kreativitas berpikir dalam matematika. Pengembangan kemampuan berpikir kreatif dalam pembelajaran matematika juga didukung oleh pemerintah yang terdapat dalam Standar Kompetensi Kurikulum 2006. Standar Kompetensi Kurikulum 2006 menyebutkan bahwa matematika perlu diberikan pada seluruh peserta didik mulai dari sekolah dasar untuk membekali peserta didik dengan kemampuan berpikir logis, analitis, sistematis, kritis dan kreatif serta kemampuan bekerjasama.

Selain itu salah satu prinsip dalam kegiatan mengajar belajar dalam kurikulum 2006 adalah mengembangkan kreativitas siswa. Dengan demikian, dalam mengembangkan kemampuan berpikir siswa, kurikulum mengisyaratkan pentingnya mengembangkan kreativitas siswa. Pengembangan kreativitas dan kemampuan berpikir kreatif siswa dilakukan melalui aktivitas-aktivitas kreatif dalam pembelajaran matematika. Kreativitas dapat dipandang sebagai produk dari berpikir kreatif, 
sedangkan aktivitas kreatif merupakan kegiatan pembelajaran yang diarahkan untuk mendorong atau memunculkan kreativitas siswa.

Menurut Ruseffendi (1991: 239), kreativitas siswa akan tumbuh jika dilatih dengan melakukan eksplorasi, inkuiri, penemuan dan pemecahan masalah. Kemampuan berpikir kreatif akan tumbuh dengan baik jika siswa belajar dengan prakarsanya sendiri, diberi kepercayaan untuk berpikir dan berani mengemukakan gagasan baru. Kemampuan berpikir kreatif juga dapat ditumbuh kembangkan melalui suatu pembelajaran yang dirancang guru sehingga dapat melatih siswa untuk mengeksplorasi segenap kemampuan yang ada didalam dirinya.

Pembelajaran matematika tidak hanya memberi tekanan pada keterampilan menghitung, mengolah, menganalisis, dan kemampuan menyelesaikan soal saja, akan tetapi sikap dan kemampuan menerapkan matematika merupakan penompang penting untuk membentuk kemampuan komunikasi sehari-hari yang akan dihadapinya kelak. Pembelajaran matematika perlu dirancang sedemikian rupa sehingga berpotensi mengembangkan kreativitas berpikir siswa dalam matematika.

Pengembangan kreativitas berpikir perlu dilakukan seiring dengan pengembangan cara mengevaluasi atau cara mengukurnya. Oleh karena itu, proses belajar matematika akan terjadi dengan lancar apabila dilakukan secara kontinu. Sing (Munandar, 1992: 56), mendefinisikan kreativitas matematis sebagai proses merumuskan hipotesis yang mengenai penyebab dan pengaruh didalam situasi matematis, pengujian, pengujian kembali hipotesis, membuat modifikasi dan akhirnya mengkomunikasikan hasil. Melalui proses pembelajaran matematika yang dilakukan secara kontinu, maka siswa akan terbiasa untuk mengoptimalkan proses berpikirnya.

Secara khusus kreativitas matematika menurut Krutetskii (Siswono, 2007: 8), merupakan suatu penguasaan kreatif mandiri matematika dalam pembelajaran matematika, perumusan mandiri masalah-masalah matematis yang tidak rumit, penemuan cara-cara atau sarana dari penyelesaian masalah, penemuan bukti-bukti teorema, pendeduksian mandiri rumus-rumus, dan penemuan metode-metode penyelesaian masalah non-standar.

Cara berpikir kreatif seharusnya dapat dikembangkan melalui pendidikan matematika. Selain itu, dalam aspek pemecahan masalah matematika, diperlukan pemikiran-pemikiran yang kreatif dalam membuat (merumuskan), menafsirkan dan menyelesaikan model atau perencanaan pemecahan masalah. Sehingga diperlukan suatu cara atau pola pikir yang tepat untuk mendorong keterampilan berpikir kreatif siswa dalam belajar matematika.

Rendahnya kemampuan berpikir kreatif juga dapat berimplikasi pada rendahnya prestasi siswa. Menurut Wahyudin (1999: 223), diantara penyebab rendahnya pencapaian siswa dalam pelajaran matematika adalah proses pembelajaran yang belum optimal. Dalam proses pembelajaran umumnya guru sibuk sendiri menjelaskan apa-apa yang telah dipersiapkannya. Demikian juga siswa 
sibuk sendiri menjadi penerima informasi yang baik. Akibatnya siswa hanya mencontoh apa yang dikerjakan guru, tanpa makna dan pengertian sehingga dalam menyelesaikan soal siswa beranggapan cukup dikerjakan seperti apa yang dicontohkan. Hal tersebut menyebabkan siswa kurang memiliki kemampuan menyelesaikan masalah dengan alternatif lain dan dapat disebabkan karena siswa kurang memiliki kemampuan fleksibilitas yang merupakan komponen utama kemampuan berpikir kreatif. Fakta menunjukkan kurangnya perhatian terhadap kemampuan berpikir kreatif dalam matematika beserta implikasinya, dengan demikian perlu adanya untuk memberikan perhatian lebih pada kemampuan ini dalam pembelajaran matematika saat ini.

Pengembangan kemampuan berpikir statistik merupakan salah satu fokus pembelajaran matematika yang diharapkan mampu untuk menumbuhkembangkan kreativitas siswa dalam pembelajaran matematika. Menurut Suriasumantri (2003: 167), berpikir statistik merupakan bagian dari sarana berpikir ilmiah yang didalamnya terdapat bagian dari berpikir logis dan sistematis. Dalam belajar statistik penguasaan kompetensi sangatlah penting, karena belajar statistik menjadi prasyarat utama siswa untuk mengetahui kemampuan berpikir statistiknya. Dengan menguasai konsep dari berpikir statistik maka akan membantu siswa dalam memahami matematika.

Melalui pembelajaran matematika siswa diharapkan memiliki kemampuan berpikir logis, analitis, sistematis, kritis, dan kreatif. Kemampuan berpikir statistik dapat ditemukan di seluruh area matematika dan penting dalam kehidupan sehari-hari, seperti yang dikatakan oleh H.G. Wells (Suriasumantri, 2003: 215), bahwa suatu hari nanti berpikir statistik akan menjadi keharusan bagi manusia seperti juga membaca dan menulis. Oleh karena itu, melalui kemampuan berpikir statistik dalam pembelajaran matematika diharapkan dapat merangsang siswa untuk menggunakan kemampuan berpikir logis, analitis, sistematis, dan kreatif, serta menggunakan kemampuan dalam menarik kesimpulan dan menyederhanakan permasalahan dari sebuah persoalan.

Berdasarkan informasi yang disampaikan oleh Ibu Nunung (Seorang Guru bidang Matematika di MAN 2 Kota Cirebon), yaitu menyatakan bahwa "mayoritas siswa hanya mengerti pada tahap ketika guru menerangkan materi pelajaran dan contoh soal. Namun, ketika siswa dihadapkan dengan soal yang sedikit berbeda dari contoh soal yang pernah mereka terima, mereka pun agak kesulitan untuk menjawab". Selain itu, berdasarkan pengamatan diketahui bahwa dalam melaksanakan pembelajaran, guru cenderung prosedural dan lebih menekankan pada hasil belajar. Siswa belajar sesuai dengan contoh yang diberikan guru, dan soal-soal yang diberikan kepada siswa hanya soal-soal yang langsung pada pemakaian rumus yang sudah ada atau soal tertutup. Akibatnya, siswa kurang berkesempatan untuk mengembangkan kreativitas berpikirnya dan produksi berpikirnya dalam memanipulasi materi matematika untuk dapat menyelesaikan soal matematika secara maksimal. 
Berdasarkan hasil studi pendahuluan tersebut, maka peneliti akan mencoba menggunakan kemampuan berpikir statistik untuk merangsang kreativitas berpikir siswa didalam matematika, yang dirumuskan dengan judul penelitian: "Pengaruh Kemampuan Berpikir Statistik Terhadap Kreativitas Berpikir Siswa Dalam Matematika” studi kasus di kelas XI MAN 2 Kota Cirebon.

\section{METODE DAN SUBJEK PENELITIAN}

Pendekatan yang digunakan dalam penelitian ini adalah pendekatan kuantitatif dengan sifat studi kasus. Metode yang digunakan dalam penelitian ini adalah metode ex-post facto. Penelitian menjelaskan tentang pengaruh kemampuan berpikir statistik terhadap kreativitas berpikir siswa dalam matematika di kelas XI MAN 2 Kota Cirebon. Penelitian ini akan mengukur seberapa besar pengaruh antara variabel $X$ (kemampuan berpikir statistik) terhadap variabel $Y$ (kreativitas berpikir siswa dalam matematika). Maka hasil dari penelitian ini hanya berlaku untuk siswa kelas XI MAN 2 Kota Cirebon, artinya tidak digeneralisasikan untuk semua siswa di MAN 2 Kota Cirebon bahkan di sekolah-sekolah lainnya.

Populasi yang diharapkan dalam penelitian ini adalah seluruh siswa atau siswi kelas X, XI, dan XII MAN 2 Kota Cirebon. Oleh karena keterbatasan waktu, biaya dan tenaga yang dimiliki oleh peneliti, maka populasi yang bisa diambil adalah kelas XI yang terdiri dari 7 kelas dan dengan jumlah 290 siswa.

Peneliti mengambil subyek sampel sebanyak 1 kelas dari 7 kelas dengan teknik non probability sampling melalui teknik purposive sampling, yaitu teknik penentuan sampel dengan pertimbangan tertentu (Sugiyono, 2009: 118). Pertimbangan tersebut didasarkan kepada Guru Pertimbangan tersebut didasarkan kepada Guru Matematika MAN 2 Kota Cirebon yang sudah berpengalaman dalam mengajar. Beliau memberikan pertimbangan untuk mengambil sampel berdasarkan kriteria tertentu. Maka, sampel yang dipilih dalam penelitian di kelas XI MAN 2 Kota Cirebon adalah kelas XI IPA 2 yang berjumlah 34 siswa.

Instrumen penelitian yang akan digunakan dalam penelitian ini adalah berupa tes uraian. Guna mengetahui keefektifan instrumen agar mendapatkan data yang sahih dan benar, maka dilakukan pengujian terhadap instrumen tersebut. Instrumen penelitian berupates uraian diuji cobakan terlebih dahulu kepada subjek uji coba. Hasil yang diperoleh dianalisis dengan menggunakan uji validitas dan reliabilitas. Setelah instrumen valid dan reliabel maka dilakukan penelitian di kelas sampel untuk memperolah data penelitian.

Data yang terkumpul dianalisis dengan uji normalitas untuk mengetahui data tersebut berdistribusi normal atau tidak dengan menggunakan rumur Chi-kuadrat. Setelah diuji normalitas langkah selanjutnya adalah melakukan uji homogenitas guna mengetahui apakah sampel memiliki sifat homogen atau tidak. Dilanjutkan dengan uji kelinieran regresi, untuk mengetahui apakah dua 
variabel mempunyai hubungan yang linier atau tidak secara signifikan. Setelah uji kelinieran regresi, langkah selanjutnya adalah mencari persamaan regresi linear (analisis regresi) yang berbentuk $\hat{Y}=a+b x$. Kemudian mencari koefisien determinasi $\left(R^{2}\right)$ untuk mengetahui besarnya prosentase varians kemampuan berpikir statistik hinga dapat mempengaruhi kreativitas berpikir siswa. Dan yang terakhir adalah dilakukannya uji hipotesis guna menjawab permasalahan koperhensif yaitu terdapat tidaknya pengaruh kemampuan berpikir statistik $(X)$ terhadap kreativitas berpikir siswa $(Y)$.

\section{HASIL PENELITIAN DAN ANALISIS DATA}

Data hasil penelitian diperoleh dari hasil instrument tes uraian kemampuan berpikir statistik dan tes kreativitas berpikir siswa. Kduan instrumen tersebut sudah diuji validitas dan reliabilitasnya di kelas uji coba dan diperoleh masing-masing 8 butir soal yang valid dan reliabel untuk instrumen kemampuan berpikir statistik, dan 6 butir soal yang valid dan reliabel untuk instrumen kreativitas berpikir siswa. Kemudian instrumen tersebut dijadikan alat untuk mengumpulkan data di kelas sampel. Data yang diperoleh digunakan sebagai data hasil penelitian dan langkah selanjutnya adalah untuk menganalisis data tersebut, peniliti menggunakan bantuan software SPSS 16.0. Adapun langkah-langkah dalam menganalisis data adalah sebagai berikut:

\section{A. Uji Normalitas}

Setelah dilakukan perhitungan uji normalitas dengan menggunakan software SPSS 16.0, dapat kita lihat pada tabel uji Shapiro-Wilk di bawah ini:

\section{Tabel 1}

Uji Normalitas Shapiro-Wilk

Tests of Normality

\begin{tabular}{|l|r|r|r|}
\hline \multirow{2}{*}{} & \multicolumn{3}{|c|}{ Shapiro-Wilk } \\
\cline { 2 - 4 } & \multicolumn{1}{|c|}{ Statistic } & \multicolumn{1}{c|}{ df } & \multicolumn{1}{c|}{ Sig. } \\
\hline Unstandardized Residual & .966 & 34 & .363 \\
\hline
\end{tabular}

Berdasarkan pengujian normalitas Error (residu) dengan uji Shapiro-Wilk pada kolom Unstandardized Residual didapat nilai signifikansi 0,363 dengan taraf signifikansi $\alpha=0,05$. Dengan demikian $p$-value Shapiro-Wilk (nilai $p$ ) > 0,05, yakni $0.363>0,05$ maka artinya error berdistribusi normal atau data tersebut semuanya berdistribusi normal.

\section{B. Uji Homogenitas}

Uji homogenitas dalam penelitian ini menggunakan uji Levene Test. Hasil yang diperoleh dari hasil SPSS 16.0 dengan menggunakan uji Levene Test, dapat dilihat pada tabel di bawah ini: 
Tabel 2

Test of Homogeneity of Variances

Kreaivitas Berpikir Siswa

\begin{tabular}{|c|c|c|c|}
\hline Levene Statistic & df1 & df2 & Sig. \\
\hline 1.701 & 6 & 22 & .168 \\
\hline
\end{tabular}

Berdasarkan hasil uji homogenitas dengan menggunakan Levene Test dapat diketahui bahwa nilai Sig. sampel yaitu 0,168 dan berada di atas 0,05. Karena nilai sig. 0,168 > 0,05, maka dengan demikian dapat disimpulkan bahwa data tersebut berdistribusi homogen.

\section{Uji Kelinieran Regresi}

Uji kelinieran regresi diperoleh data hasil perhitungan sebagai berikut.

Tabel 3

ANOVA Table

\begin{tabular}{|c|c|c|c|c|c|c|}
\hline & & $\begin{array}{l}\text { Sum of } \\
\text { Squares }\end{array}$ & df & $\begin{array}{l}\text { Mean } \\
\text { Square }\end{array}$ & $\mathrm{F}$ & Sig. \\
\hline \multirow{5}{*}{$\begin{array}{l}\text { Kreaivitas Berpil } \\
\text { Siswa } \\
\text { Kemampuan } \\
\text { Berpikir Statistik }\end{array}$} & (Combined) & 942.104 & 11 & 85.646 & 2.957 & .015 \\
\hline & Linearity & 597.495 & 1 & 597.495 & 20.627 & .000 \\
\hline & $\begin{array}{l}\text { Deviation from } \\
\text { Linearity }\end{array}$ & 344.609 & 10 & 34.461 & 1.190 & .349 \\
\hline & Within Groups & 637.252 & 22 & 28.966 & & \\
\hline & Total & 1579.356 & 33 & & & \\
\hline
\end{tabular}

Berdasarkan nilai signifikan pada baris Linearity sebesar 0,000. Hal ini mengindikasikan bahwa antara variabel kemampuan berpikir statistik dengan variabel kreativitas berpikir siswa terdapat hubungan yang linear, karena nilai signifikansi kurang dari 0,05.

\section{Persamaan Regresi}

Analisis regresi diperoleh hasil sebagai berikut.

Tabel 4

Coefficients $^{a}$

\begin{tabular}{|c|c|c|c|c|c|}
\hline \multirow[b]{2}{*}{ Model } & \multicolumn{2}{|c|}{$\begin{array}{l}\text { Unstandardized } \\
\text { Coefficients }\end{array}$} & \multirow{2}{*}{\begin{tabular}{|c|}
$\begin{array}{c}\text { Standardized } \\
\text { Coefficients }\end{array}$ \\
Beta
\end{tabular}} & \multirow[b]{2}{*}{$\mathrm{T}$} & \multirow[b]{2}{*}{ Sig. } \\
\hline & B & Std. Error & & & \\
\hline $1 \quad$ (Constant) & 34.901 & 8.225 & & 4.243 & .000 \\
\hline $\begin{array}{l}\text { Kemampuan } \\
\text { Berpikir Statistik }\end{array}$ & .552 & .125 & .615 & 4.413 & .000 \\
\hline
\end{tabular}

a. Dependent Variable: Kreaivitas Berpikir

Siswa 
Diketahui nilai sig. dari konstanta $=0,000<0,05$. Dengan demikian persamaan regresi untuk kedua variabel tersebut adalah: $\widetilde{Y}=34,901+0,552 X$. Dari persamaan tersebut dapat dijelaskan apabila seorang siswa tidak mempunyai kemampuan berpikir statistik, diperkirakan kreativitas berpikir siswa tersebut hanya sebesar 34,901.

\section{E. Uji Kebaikan Model}

Uji ini digunakan untuk mengetahui seberapa besar kontribusi variabel kemampuan berpikir statistik $(X)$ mempengaruhi variabel kreativitas berpikir siswa $(Y)$.

Tabel 5

Model Summary

\begin{tabular}{|l|r|r|r|r|}
\hline Model & $\mathrm{R}$ & R Square & \multicolumn{1}{|c|}{$\begin{array}{c}\text { Adjusted R } \\
\text { Square }\end{array}$} & $\begin{array}{c}\text { Std. Error of the } \\
\text { Estimate }\end{array}$ \\
\hline 1 & $.615^{\mathrm{a}}$ & .378 & .359 & 5.53924 \\
\hline
\end{tabular}

a. Predictors: (Constant), Kemampuan Berpikir Statistik

b. Dependent Variable: Kreaivitas Berpikir Siswa

Koefisien determinasi dapat di lihat pada $R$ Square sebesar 0,378 atau 37,8\%. Hal ini menunjukkan adanya kontribusi dari kemampuan berpikir statistik $(X)$ terhadap kreativitas berpikir siswa $(Y)$ sebesar 37,8\% sedangkan sisanya sebesar 62,2\% lainnya dijelaskan oleh variabel lain di luar variabel yang digunakan dalam penelitian ini.

\section{F. Uji Hipotesis}

Uji hipotesis didapat sebagai berikut.

Tabel 6

Coefficients $^{\mathrm{a}}$

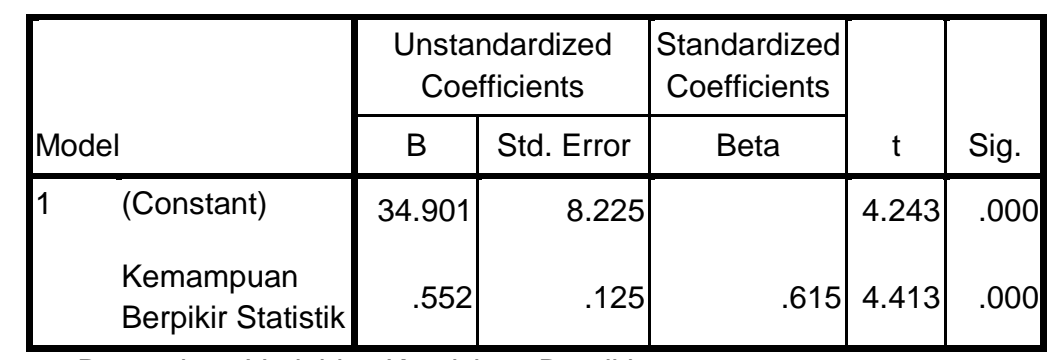

a. Dependent Variable: Kreaivitas Berpikir

Siswa

Tabel Coefficients menunjukkan nilai $t_{\text {hitung }}$ sebesar 4,413 serta signifikansi sebesar 0,000. Untuk $t_{\text {tabel }}$ dicari pada taraf signifikan 5\% dengan derajat kebebasan 32, diperoleh $t_{\text {tabel }}$ sebesar 2,037. Karena $t_{\text {hitung }}(4,413)$ lebih besar dari $t_{\text {tabel }}(2,037)$ maka $H_{o}$ ditolak, artinya terdapat pengaruh antara kemampuan berpikir statistik $(X)$ terhadap kreativitas berpikir siswa $(Y)$. 


\section{INTERPRETASI DAN PEMBAHASAN}

Berpikir statistik merupakan bagian dari berpikir matematika akan tetapi berpikir statistik tidaklah sama dengan berpikir matematika. Jika matematika mepunyai peranan yang penting dalam berpikir deduktif, maka kemampuan berpikir statistika mempunyai peranan penting dalam berpikir induktif. Pengembangan kemampuan berpikir statistik diharapkan dapat menumbuhkembangkan kreativitas siswa pada fokus materi pembelajaran matematika mengenai statistik dan peluang.

Hasil analasis persamaan regresi untuk kedua variabel tersebut menunjukkan persamaan $\hat{Y}=34,901+0,552 X$. Persamaan tersebut mengandung arti bahwa jika tanpa kemampuan berpikir statistik, maka kreativitas berpikir siswa sebesar 34,901. Koefisien regresi sebesar 0,552 menyatakan bahwa setiap peningkatan kemampuan berpikir statistik akan mempengaruhi kreativitas berpikir siswa sebesar 0,552 kali.

Hasil tersebut serupa dengan hasil riset C.J. Wild \& M. Pfannkuch (2004) yang menyatakan bahwa "...The usual panacea for "teaching" students to think statistically is, with apologies to Marie-Antoinette, "let them do projects". Although this enables students to experience more of the breadth of statistical activity, experience is not enough. The cornerstone of teaching in any area is the development of a theoretical structure with which to make sense of experience, to learn from it and transfer insights to others...". Dijelaskan bahwa cara terbaik mengajar siswa untuk berpikir statistik menurut Marie-Antoinette adalah "biarkan mereka melakukan proyek" karena hal ini memungkinkan siswa untuk mengalami hal lebih dari semua kegiatan statistik, karena pengalaman tidaklah cukup, namun landasan mengajar dan pengembangan struktur teoritislah yang dapat digunakan untuk memahami pengalaman belajar itu sendiri agar mampu mentransfer wawasan yang didapat kepada orang lain.

Hal ini pula dijelaskan oleh S. Imtiaz A dalam jurnalnya (2002) bahwa “... Creative thinking in statistical thinking is about looking at possibilities in understanding objects or phenomena. It generally involves describing objects or phenomena, making projections on what is likely to happen in observed objects or phenomena with movements in time and space, and taking actions about objects or phenomena in order to move them in a desired direction...".

Artinya berpikir kreatif pada konteks berpikir statistik adalah tentang melihat kemungkinan dalam memahai obyek atau fenomena yang biasanya melibatkan gambar, membuat kesimpulan tentang apa yang mungkin terjadi pada objek yang diamati, dan mengambil tindakan tentang obyek tersebut dalam rangka memindahkan atau mengarakan pada arah yang mereka inginkan.

Berdasarkan teori diatas bahwasanya utuk menumbuhkembangkan kreativitas berpikir siswa melalui kemampuan berpikir statistik dapat dilakukan dengan memberikan beberapa kasus atau soal matematika yang berkaitan dengan statistik, peluang, mapun soal matematika lainnya. Karena 
semakin banyak siswa melakukan proyek atau mengerjakan berbagai macam soal statistik maupun matematika, maka akan semakin banyak pula pengalaman yang mereka dapat untuk lebih kreatif dalam memahami soal-soal yang bersifat terbuka lainnya.

Berdasarkan hasil analisis regresi, kemampuan berpikir statistik merupakan salah satu faktor penunjang kreativitas berpikir siswa dalam pembelajaran matematika ketika siswa memasuki materi statistik dan peluang. Siswa yang dapat menguasai kemampuan berpikir statistik dengan baik cenderung lebih mahir dalam menyelesaikan soal-soal matematika yang diberikan oleh guru, sehingga dapat menciptakan kreativitas berpikir yang baik ketika mereka memasuki materi peluang setelah materi statistik. Namun, siswa yang belum dapat menguasai kemampuan berpikir dengan baik dengan baik cenderung agak kesulitan untuk menciptakan kreativitas berpikir ketika mereka diberikan beberapa kasus mengenai soal peluang yang berasal dari teori statistika.

Hal ini menunjukkan bahwa konsep dasar statistik merupakan pengetahuan dan kemampuan dasar yang harus dikuasai terlebih dahulu sebelum mempelajari materi peluang selanjutnya. Ini artinya, bahwa semakin tinggi siswa dapat menguasai konsep dasar statistika dengan baik, maka siswa akan cenderung lebih mahir dalam menyelesaikan soal-soal matematika, baik itu soal statistik, peluang, maupun soal matematika lainnya yang diberikan oleh guru, sehingga dapat menciptakan kreativitas berpikir yang baik ketika menyelesaikan soal-soal selanjutnya.

Skor mean kemampuan berpikir statistik dari penelitian ini menunjukkan rata-rata sebesar 65,29, yang artinya bahwa secara keseluruhan kemampuan siswa dalam berpikir statistik dapat dikategorikan cukup. Pada variabel kreativitas berpikir siswa dalam matematika menunjukkan skor mean sebesar 70,96, hal ini dapat diartikan bahwa kreativitas berpikir siswa-siswi MAN 2 Kota Cirebon masuk kedalam kategori kreatif.

Dalam penelitian ini, diperoleh nilai sebesar 4,413, sehingga $t_{\text {hitung }}>t_{\text {tabel }}(4,413>2,037)$. Dengan menggunakan bantuan program SPSS 16.0 diperoleh nilai signifikan $t$ sebesar $0,000<0,05$, ini menjelaskan bahwa $H_{a}$ diterima dan $H_{0}$ ditolak, artinya terdapat pengaruh kemampuan berpikir statistik $(\mathrm{X})$ terhadap kreativitas berpikir siswa dalam matematika (Y).

\section{KESIMPULAN}

Berdasarkan hasil penelitian yang telah dideskripsikan, dianalisis dan dibahas sesuai dengan ketentuan, maka penelitian yang berjudul "Pengaruh Kemampuan Berpikir Statistik terhadap Kreativitas Berpikir Siswa dalam Matematika" (Studi Kasus di Kelas XI IPA MAN 2 Kota Cirebon) diperoleh kesimpulan sebagai berikut:

1. Kemampuan berpikir statistik siswa memiliki rata-rata sebesar 65,29 , dengan skor minimum 50.00 dan skor maximum 85.00. Simpangan baku sebesar 7,71 dan median sebesar 65,00. Hal 
ini dapat disimpulkan bahwa tingkat kemampuan berpikir statistik siswa kelas XI MAN 2 Kota Cirebon secara keseluruhan tergolong "cukup".

2. Tingkat kriteria kreativitas berpikir siswa kelas XI MAN 2 Kota Cirebon dalam matematika diketahui secara keseluruhan termasuk kedalam kategori kreatif. Hal ini dikarenakan kreativitas berpikir siswa dalam matematika memiliki rata-rata nilai tes sebesar 70,96 dan simpangan baku sebesar 6,92 dengan median 70,83. Kriteria kreatif ini berarti siswa mampu menunjukkan satu jawaban yang baru dengan cara penyelesaian yang berbeda (fleksibel) meskipun tidak fasih, dalam kata lain membuat berbagai jawaban yang baru walaupun tidak menggunakan cara yang berbeda. Selain itu, siswa mampu menyelesaikan masalah yang berbeda dengan lancar (fasih) meskipun langkahnya masih belum terinci.

3. Berdasarkan hasil uji regresi, diperoleh koefisien determinasi sebesar 37,8\% dengan persamaan regresi yaitu .. Hal ini menunjukkan bahwa setiap ada peningkatan kemampuan berpikir statistik, maka akan mempengaruhi kreativitas berpikir siswa sebesar 0,552 kali, sedangkan koefisien determinasi sebesar 37,8\% dapat diartikan sebagai besarnya pengaruh kemampuan berpikir statistik terhadap kreativitas berpikir siswa dalam matematika dan sisanya sebesar $62,2 \%$ lainnya dijelaskan oleh variabel lain di luar variabel yang digunakan dalam penelitian ini. Jadi, dapat disimpulkan bahwa kemampuan berpikir statistik berpengaruh terhadap kreativitas berpikir siswa dalam matematika.

\section{SARAN}

Berdasarkan kesimpulan dalam penelitian ini, penulis mengajukan beberapa saran sebagai berikut:

1. Guru diharapkan dapat menumbuhkembangkan kemampuan berpikir statistik siswa agar mampu merangsang kreativitas berpikir dalam pembelajaran matematika khususnya, ketika siswa memasuki sub pokok bahasan matematika lainnya. Merencanakan pembelajaran efektif dengan persiapan yang optimal, serta mampu mengembangkan kreativitas berpikir siswa dalam matematika.

2. Siswa harus belajar mengoptimalkan kemampuan berpikir statistiknya dengan baik, belajar aktif, selalu semangat, senang dan mampu berpikir kreatif agar dapat menciptakan kreativitas berpikir yang tinggi.

3. Untuk peneliti yang selanjutnya diharapkan melakukan penelitian mengenai kemampuan berpikir statistik terhadap kreativitas berpikir siswa dalam matematika, sasaran penelitian kelas XI MAN 2 Kota Cirebon dapat memilih variabel-variabel lain baik variabel terikatnya maupun variabel bebasnya, seperti terhadap kemampuan berpikir kritis, keterampilan bernalar, problem solving dan lain sebagainya. 


\section{DAFTAR PUSTAKA}

1. Ahmad, Syed Imtiaz. 2002. Statistical Inferences and Creative Thinking (Creative Thinking And Statistics). [Online]. Tersedia: http://www.onislam.ac.id/english/shariah/contemporaryissues/scientificdomain-statistically/416864.doc

2. Amirrulah, Imam. 2011. Matematika dan Statistika Sebagai Sarana Berpikir Ilmiah. Jurnal Makalah. [Online]. Tersedia:http://imam201131014.esaunggul.ac.id/files/makalah/page.4.doc. $\% 2$ Fwpcontent $\%$ 2Fuploads $\% 2$ Fsites $\% 2 F 451 \% 2$ F2013\%2F05\%2FMATEMATIKA-DANSTATISTIKA-SEBAGAI-SARANA-BERFIKIRILMIAH.doc\&ei=Oc3jUfaADIiKrQe 4YCoDw\&usg=AFQjCNF7oZboelPEEUxln4Is9K3fxUvoQ\&sig2=hs3eHonqcqEvWxGHDyvn 2w\&bvm=bv.48705608,d.dmg.

3. Arikunto, Suharsimia. 2007. Manajemen Penelitian. Jakarta: Rineka Cipta.

4. 2006. Manajemen Penelitian. Jakarta: Rineka Cipta.

5. Depdiknas. 2006. Kurikulum 2006. Standar Kompetensi Mata Pelajaran Matematika Sekolah Menengah Atas. Jakarta: Depdiknas.

6. Hasan, M. Iqbal. 2002. Metodologi Penelitian dan Aplikasinya. Bogor: Ghalia Indonesia.

7. Indah S, Meilia Nur. 2010. Statistika Deskriptif \& Induktif. Yogyakarta: Graha Ilmu.

8. Izzati, Nur. 2009. Berpikir Kreatif dan Kemampuan Pemecahan Masalah

9. Matematis: Apa, Mengapa, dan bagaimana mengembangkannya pada

10. peserta didik. Prosiding Seminar Nasional Matematika dan Pendidikan Matematika, Bandung 19 Desmber 200. [Online]. Tersedia:http://bundaizza.wordpress.com/page16.pdf/

11. Kurniasih, Icih. 2011. Pengaruh Emotional Quotient (EQ) Terhadap Kreativitas Berpikir Siswa. Skripsi. Tidak diterbitkan. Cirebon: IAIN Syekh Nurjati Cirebon.

12. Kusmanto, Hadi. 2004. Korelasi antara Realictic Mathematics Education (RME) Dengan Kreativitas Berfikir Siswa (Studi Tentang Upaya Menumbuhkembangkan Kreativitas Berpikir Siswa di SMPN 1 Plumbon). Skripsi. Tidak diterbitkan. Cirebon: STAIN Cirebon.

13. Machrus, Agus. 2012. Pengaruh Kemampuan Berpikir Aljabar Terhadap Kreativitas Berpikir Siswa Dalam Matematika (Studi Kasus di Kelas XI IPA SMAN 1 Dukupuntang Kecamatan Dukupuntang Kabupaten Cirebon). Skripsi. Tidak diterbitkan. Cirebon: IAIN Syekh Nurjati Cirebon.

14. Mahmudi, Ali. 2008. Pemecahan Masalah dan Berpikir Kreatif. Makalah. Disampaikan Pada Konferensi Nasional Matematika (KNM) XIV Universitas Sriwijaya Palembang, 24-27 Juli 2008. [Online].

Tersedia: http://staff.uny.ac.id/sites/default/files/penelitian/Ali\%20Mahmudi,\%20S.Pd,\%20M.Pd,\%20Dr. /Makalah\%2001\%20KNM\%20UNSRI\%202008\%20Pemecahan\%20Masalah\%20\&\%20Berpik ir\%20Kreatif.pdf 
15. Martadiputra. (2010). Diklat Kemampuan Melek Statistis (Statistical literacy), Penalaran Statistis (Statistical Reasoning) dan Berpikir Statistis (Statistical Thinking) Guru SMP/SMA. Bandung: Jurnal Albamas tahun 10, No. 10, Oktober 2010, ISSN 1412-1891. [Online]. Tersedia:http://jurnal.upi.edu/file/Bambang_A.pdf

16. Martadiputra dan Didi Suryadi. 2012. Peningkatan Kemampuan Berpikir Statistis Mahasiswa S1 Melalui Pembelajaran MEAs yang Dimodifikasi. Bandung: Jurnal Ilmiah Program Studi $\begin{array}{llll}\text { Matematika STKIP Siliwangi Bandung. } & \text { S }\end{array}$ [Online]:Tersedia:http://publikasi.stkipsiliwangi.ac.id/files/2012/08/Bambang-Avip.pdf

17. Munandar, Utami S.C. 1992. Mengembangkan Bakan dan Kreativitas Anak Sekolah. Jakarta: Gramedia

18. Nuraenafisah. 2012. Pengaruh Penggunaan Scratch Terhadap Kreativitas Berpikir Matematis. Skripsi. Tidak diterbitkan. Cirebon: IAIN Syekh Nurjati Cirebon.

19. Nurhayati, Eti. 2011. Psikologi Pendidikan Inofatif. Yogyakarta: Pustaka Setia.

20. Rahmawati, Yeni dan Euis Kurniati. 2011. Strategi Pengembangan Kreatifitas Pada Anak Usia Taman Kanak-kanak. Jakarta: Kencana.

21. Riduwan. 2008. Belajar Mudah Penelitian Untuk Guru-Karyawan Dan Peneliti Pemula. Bandung: Alfabeta.

22. Riduwan dan Sunarto. 2007. Pengantar Statistik untuk Penelitian Pendidikan, Sosial, Ekonomi, Komunikasi dan Bisnis. Bandung: Alfabeta.

23. Ruseffendi, E. T. 1991. Pengantar Kepada Guru Mengembangkan Kompetensinya Dalam Pengajaran Matematika Untuk Meningkatkan CBSA. Bandung: Tarsito.

24. Semiawan, Conny, dkk. 2009. Memupuk Bakat dan Kreativitas Siswa Sekolah Menengah. Jakarta: Gramedia.

25. Shaleh, Abdul Rahman. 2004. Psikologi Suatu Pengantar dalam Perspektif Islam. Jakarta: Kencana.

26. Siregar, Syofian. 2010. Statistika Deskriptif Untuk Penelitian. Jakarta: Raja Grafindo Persada.

27. Snee, Ronald. D. (1990). Statistical Thinking and Its Contribution to Total Quality, The American Statistikian, 44, 116-121. [Online]. Tersedia: http://rube.asq.org/statistics/2011/10/continuous-improvement/statisticalthinking-and-itscontribution-to-total-quality.pdf

28. Subana. 2005. Statistik Pendidikan. Bandung: CV Pustaka Setia.

29. Sudijono, Anasa. 1996. Pengantar Evaluasi Pendidikan. Jakarta: PT Raja Grafindo Persada. 30. 2008. Pengantar Statistika Pendidikan. Jakarta: PT Raja Grafindo Persada.

31. Sudjana, Nana. 1990. Penilaian Hasil Proses Belajar Mengajar. Bandung: Rosdakarya.

32. Sugiyono. 2007. Metode Penelitian Bisnis, Cetakan Kesepuluh. Bandung:Alfabeta 
33. .2009. Metode Penelitian Pendidikan: Pendektan Kuantitatif, Kualitatif dan R\&D. Bandung: Alfabeta.

34. Suherman, Erman dan Yaya Sukjaya. 1990. Petunjuk Praktis untuk Melaksanakan Evaluasi Pendidikan Matematika. Bandung: Wijayakusumah.

35. Surapranata, Sumarna. 2004. Analisis, Validitas, Reliabilitas dan Interpretasi Hasil Tes Implementasi Kurikulum 2004. Bandung: PT Remaja Rosda Karya.

36. Suriasumantri, S Jujun. 2003. Filsafat Ilmu: Sebuah Pengantar Populer. Jakarta: Pustaka Sinar Harapan.

37. Suyanto, dkk. 2000. Refleksi dan Reformasi Pendidikan di Indonesia Memasuki Milenium III. Yogyakarta: Adi Cita Karya Nusa.

38. Wahyudin. 1999. Kemampuan Guru Matematika, Calon Guru Matematik, dan Siswa dalam Mata Pelajaran Matematika. Bandung: PPS IKIP Bandung.

39. Wild, C. J. and Pfannkuch, M. 1999. Statistical Thinking in Empirical Enquiry, International Statistical Review. 67, 223-265. Department of Statistics, University of Auckland, Private Bag 92019, Auckland, New Zealand. [Online].Tersedia:http://www.stat.auckland.ac.nz/ iase/publications/isr/99

40. Yamin, Sofyan dkk. 2011. Regresi dan Korelasi dalam Genggaman Anda. Jakarta: Salemba Empat.

41. Yuli, Tatag Eko Siswono. 2007. Penjenjangan Kemampuan Berpikir Kreatif dan Identifikasi Tahap Berpikir Kreatif Siswa dalam Memecahkan dan Mengajukan Masalah Matematika. Ringkasan disertasi. [Online].

Tersedia.http://suaraguru.atrht.ac/ publish/Pmd2bRigbknnyN3/009WuJ/A \&cad-rda.pdf 